\title{
Investigation of stability of gold nanoparticles modified zinc-cobalt coating in an alkaline sodium borohydride solution
}

Aušrinè Zabielaitė $\dot{e}^{*}$

Dijana Šimkūnaitè,

Aldona Balčiūnaitè,

Birutè Šimkūnaitè-Stanynienè,

Irena Stalnionienè,

Leonas Naruškevičius,

Daina Upskuvienė,

Algirdas Selskis,

Loreta Tamašauskaitè-Tamašiūnaitè,

Eugenijus Norkus

State Research Institute

Center for Physical Sciences and Technology,

3 Sauletekio Avenue,

10257 Vilnius, Lithuania
The electrochemical stability and durability of $\mathrm{ZnCo}$ alloy thin layers deposited on the titanium surface (denoted as $\mathrm{ZnCo} / \mathrm{Ti}$ ) and those modified by small amounts of Au nanoparticles (denoted as AuZnCo/Ti) prepared via the electrochemical metal deposition technique and a simple galvanic displacement have been investigated in alkaline sodium borohydride $\left(\mathrm{NaBH}_{4}\right)$ solutions. The physical properties of the fabricated AuZnCo/Ti catalysts have been examined using field emission scanning electron microscopy (FESEM), energy dispersive X-ray analysis (EDX) and inductively coupled plasma optical emission spectroscopy (ICP-OES). The electrocatalytic activity of the $\mathrm{ZnCo} / \mathrm{Ti}$ and $\mathrm{AuZnCo} / \mathrm{Ti}$ catalysts toward the oxidation of $\mathrm{NaBH}_{4}$ has been evaluated in an alkaline medium using cyclic voltammetry $(\mathrm{CV})$ and chronoamperometry $(\mathrm{CA})$, whereas the catalytic efficiency of the catalysts for the hydrolysis reaction of $\mathrm{NaBH}_{4}$ has been also examined by measuring the amount of generated hydrogen via the classic water-displacement method.

It has been determined that the modification of the $\mathrm{ZnCo}$ alloy coating by Au nanoparticles apparently improves not only the morphology and structure of the catalyst, but also the activity and stability of the one for the oxidation of $\mathrm{NaBH}_{4}$ in an alkaline medium as compared to those of $\mathrm{ZnCo} / \mathrm{Ti}$ and bare Au. The AuZnCo/Ti catalysts that have Au loadings of 63 and $306 \mu \mathrm{g} \mathrm{cm}^{-2}$ give ca. 12 and 11, respectively, times higher $\mathrm{NaBH}_{4}$ oxidation current densities as compared to those of the bare $\mathrm{Au}$ catalyst. Moreover, the AuZnCo/Ti catalysts catalyze the hydrolysis reaction of $\mathrm{NaBH}_{4}$ in alkaline solutions.

Keywords: Au nanoparticles, $\mathrm{ZnCo}$, electrochemical deposition, galvanic displacement, borohydride oxidation

\section{INTRODUCTION}

Serious global energy and environmental problems face the requirement to minimize the dependence on fossil fuel-fed systems and substitute them by alternative ones. Among the most fascinating systems

\footnotetext{
*Corresponding author. Email: ausrine.zabielaite@ftmc.lt
}

are those based on the fuel cell that are progressively entering the market due to their intrinsic high efficiency, virtually pollutant-free and quiet operation, ultra-clean energy, fuel flexibility, reliability and scalability to a range of applications, from small electronics to large power plants. From that point of view, the direct borohydride fuel cell (DBFC) is regarded as a greatly promising one [1-3], especially, 
for realization of its potentials in portable and mobile electronic devices [2, 4, 5, The comprehensive benefit of DBFCs is the fuel that is quite stable in an alkaline medium, generates environment-friendly and soluble in water oxidation products and has several strong advantages of safety, efficiency and energy density when compared to the other fuels used. However, some serious drawbacks concerning their successful commercialization related to a relatively high cost and scarcity of catalysts in a conjunction with their insufficient activity, durability and stability emerge. The best and the most commonly used catalysts in DBFCs are still the noble ones, including $\mathrm{Au}$ [6-10], Pd [11, 12] and particularly emphasizing Pt [0, 10, 13] that is yet top-ranked for the $\mathrm{NaBH}_{4}$ oxidation reaction (BOR). The necessity to overcome challenges towards DBFC's commercial viability related to a high cost and scarcity of the catalysts has initiated the search for alternative cheaper and more available substitutes with a high activity towards the BOR to replace the precious ones. Bi-metallic or multi-metallic systems with non-precious transition metals such as $\mathrm{Au}-\mathrm{Cu}$ [14], $\mathrm{Au}-\mathrm{Co}$ [15-17], $\mathrm{Au}-$ $\mathrm{Fe}$ [18], $\mathrm{Au}-\mathrm{Ni}$ [19-21], $\mathrm{Au}-\mathrm{Zn}[22], \mathrm{Ag}-\mathrm{Cu}$ [23], $\mathrm{Pt}-\mathrm{Cu}$ [24], Pt-Co [25-27], Pt-Ni [27], Pt-Zn [28], $\mathrm{Pd}-\mathrm{Zn}[29], \mathrm{Au} / \mathrm{Co} / \mathrm{Cu}[16]$ and $\mathrm{Cu}-\mathrm{Ni}-\mathrm{AuNi}[30]$ have been developed. Recent electrochemical studies suggest that the employment of the Pt- or $\mathrm{Au}-$ based binary electrocatalysts, denoted as PtM or AuM ( $\mathrm{M}=\mathrm{Co}, \mathrm{Ni}, \mathrm{Cu}, \mathrm{Fe}, \mathrm{Zn})$, not only permits controlling the content of the catalyst, but also definitely improves catalytic characteristics like activity and stability towards the BOR as compared to those of monometallic ones and, therefore, these catalysts are highly preferred $[14,17,22,26,27,31-36$.

The necessity of cost-effective catalysts with a relatively more pronounced characteristic has generated the idea of a complete replacement of the precious metals in the catalyst. Excellent noble metal-free single-, double- and multiple-component catalytic materials for the BOR have been created and investigated. Complete replacement of the precious metal by a non-precious one in the binary catalyst followed by their supporting on a relevant non-precious substrate with pronounced outstanding properties has been tested. Nowadays, non-precious systems, such as $\mathrm{Ni}-\mathrm{Cr}$ [37], $\mathrm{Ni}$ / $\mathrm{ZnNi} / \mathrm{Ni} / \mathrm{Cu}$ [38] and CoNiMnB [39], are particularly attractive; however, they have not yet been adequately studied and call for further investiga- tions. Alternative techniques of partial or full replacement of a non-precious metal by the precious one have also been used. The simple galvanic replacement of $\mathrm{Zn}$ by Au or Pd in the Ni-Zn coating enabled the fabrication of stable nanostructures of $\mathrm{Cu} / \mathrm{Ni} / \mathrm{AuNi}$ [30] or $\mathrm{Ni} / \mathrm{PdNi}$ [40] with a reduced content of a noble metal that seem to be promising anode catalysts for the DBFCs.

In our previous work [45], we have found that an alternative noble metal-free binary system constituted of two non-precious metals such as a ZnCo alloy and modified with negligible amounts of Au nanoparticles shows electrocatalytic activity for the oxidation of $\mathrm{NaBH}_{4}$ and hydrazine $\left(\mathrm{N}_{2} \mathrm{H}_{4}\right)$ in an alkaline medium. Relaying on the necessity of the development of efficient low-cost stable and durable catalysts for DBFCs, in the present study we investigated the electrochemical stability and durability of $\mathrm{ZnCo}$ alloy thin layers deposited on the titanium surface (denoted as $\mathrm{ZnCo} / \mathrm{Ti}$ ) and those modified by a small amount of $\mathrm{Au}$ nanoparticles (denoted as $\mathrm{AuZnCo} /$ Ti) in the alkaline $\mathrm{NaBH}_{4}$ solutions. A simple twostep approach, which involves an electrochemical deposition of the ZnCo alloy coating onto the titanium surface followed by its modification with $\mathrm{Au}$ nanoparticles by the galvanic displacement technique $[17,20,21,35,36,41,42]$, has been used for the preparation of $\mathrm{Au}$ nanoparticles modified $\mathrm{ZnCo} /$ Ti catalyst. The electrocatalytic activity of the prepared catalysts has been investigated for the BOR in an alkaline medium using cyclic voltammetry (CV) and chronoamperometry (CA). Field emission scanning electron microscopy (FESEM), energy dispersive X-ray analysis (EDX) and inductively coupled plasma optical emission spectroscopy (ICP-OES) have been used for the characterization of the morphology, structure and composition of the prepared catalysts.

\section{EXPERIMENTAL}

\section{Chemicals}

$\mathrm{CoSO}_{4}, \mathrm{ZnO}, \mathrm{HAuCl}_{4}$ and $\mathrm{NaBH}_{4}$ were purchased from Sigma-Aldrich Supply. $\mathrm{H}_{2} \mathrm{SO}_{4}$ and $\mathrm{NaOH}$ were purchased from Chempur Company. Titanium (Ti) foil of $99.7 \%$ purity and $0.127 \mathrm{~mm}$ thickness (Sigma-Aldrich) was used as a substrate. All chemicals were of analytical grade. Deionized water with a resistivity of $18.2 \mathrm{M} \Omega \mathrm{cm}^{-1}$ was used to prepare all the solutions. 


\section{Fabrication of catalysts}

In this study, the $\mathrm{ZnCo} / \mathrm{Ti}$ and $\mathrm{AuZnCo} / \mathrm{Ti}$ catalysts were prepared in the same manner as described in Refs. [43-45]. Briefly, prior to the electrodeposition of $\mathrm{ZnCo}$ alloy coating on the $\mathrm{Ti}$, the Ti plates with a geometric area of $2 \mathrm{~cm}^{2}$ were degreased with acetone, pre-treated with $\mathrm{SiC}$ emery paper (grade 2500) and $\mathrm{MgO}$ powder and rinsed with deionized water. Then, the samples were etched in a diluted $\mathrm{H}_{2} \mathrm{SO}_{4}(1: 1 \mathrm{vol})$ solution at $90^{\circ} \mathrm{C}$ temperature for $10 \mathrm{~s}$ and finally rinsed with deionized water. After that, the $\mathrm{ZnCo}$ coatings with a thickness of $\sim 5 \mu \mathrm{m}$ were electroplated on the Ti surface using an electrolyte as described in Refs. [43, 44]. Then, Au nanoparticles were deposited on the as-prepared $\mathrm{ZnCo} / \mathrm{Ti}$ surface via the galvanic displacement technique [45] by dipping of the latter catalyst into a solution containing $1 \mathrm{mM} \mathrm{HAuCl}_{4}+0.1 \mathrm{M} \mathrm{HCl}$ at $25^{\circ} \mathrm{C}$ temperature for $0.5,1$ and $5 \mathrm{~min}$, respectively. The surface-to-volume ratio was $1.3 \mathrm{dm}^{2} \mathrm{l}^{-1}$. After plating, the samples were taken out, thoroughly rinsed with deionized water and air dried at room temperature. Then, the prepared catalysts were used for measurements of the BOR as well as for the hydrolysis reaction of $\mathrm{NaBH}_{4}$ in an alkaline medium without any further treatment.

\section{Physical characterization of catalysts}

The morphology and composition of the fabricated catalysts were characterized using a SEM-focused ion beam facility (Helios Nanolab 650) equipped with an EDX spectrometer (INCA Energy 350 X-Max 20).

$\mathrm{Au}$ metal loadings in the catalysts were determined by ICP-OES measurements by recording the ICP optical emission spectra with an Optima $7000 D V$ (Perkin Elmer) spectrometer at wavelengths of $\lambda=267.595$ and $242.795 \mathrm{~nm}$. For calibration, the standard solutions of 1.0 and $10.0 \mathrm{mg} \mathrm{l}^{-1}$ were used (Perkin Elmer).

\section{Electrochemical measurements}

A conventional three-electrode electrochemical cell was used for electrochemical measurements for the BOR. The bare $\mathrm{Au}, \mathrm{AuZnCo} / \mathrm{Ti}$ and $\mathrm{ZnCo} / \mathrm{Ti}$ catalysts were employed as working electrodes, a Pt sheet was used as a counter electrode and an $\mathrm{Ag} / \mathrm{AgCl} / \mathrm{KCl}$ (3 M KCl) electrode was used as reference. An Au-sputtered quartz crystal with a geometric area of $0.636 \mathrm{~cm}^{2}$ was used as a bare gold electrode. All electrochemical measurements were performed with a Metrohm Autolab potentiostat (PGSTAT100) using the Electrochemical Software (Nova 1.6.013). Continuous cyclic voltammograms (CVs) were recorded in a $0.05 \mathrm{M} \mathrm{NaBH}_{4}+1 \mathrm{M}$ $\mathrm{NaOH}$ solution at a scan rate of $10 \mathrm{mV} \mathrm{s}^{-1}$ at $25^{\circ} \mathrm{C}$ temperature. The presented current densities were normalized with respect to the geometric area of catalysts. All solutions were deaerated by argon for 30 min prior to the measurements.

Chronoamperometric measurements were carried out on the investigated catalysts in a $0.05 \mathrm{M}$ $\mathrm{NaBH}_{4}+1 \mathrm{M} \mathrm{NaOH}$ solution at a constant potential value of $-0.2 \mathrm{~V}$ for $2 \mathrm{~min}$. The potential was initially held at open circuit for $10 \mathrm{~s}$, then set to $-0.2 \mathrm{~V}$ for $2 \mathrm{~min}$.

\section{Hydrogen generation measurements}

The amount of generated hydrogen $\left(\mathrm{H}_{2}\right)$ was measured using the classic water-displacement method with the aim to determine the catalytic efficiency of the $\mathrm{AuZnCo} / \mathrm{Ti}$ catalysts for the hydrolysis reaction of $\mathrm{NaBH}_{4}$. Typically, a reaction solution containing $0.05 \mathrm{M} \mathrm{NaBH}_{4}$ and $1 \mathrm{M} \mathrm{NaOH}$ was placed into a thermostatically controlled airtight flask fitted with an outlet for collection of the evolved $\mathrm{H}_{2}$ gas. Then, the AuZnCo/Ti catalysts were dipped into the solution at the designated temperature in order to initiate the hydrolysis of $\mathrm{NaBH}_{4}$. The water displaced from the calibrated cylinder connected to the reaction flask was continuously monitored during the performance of the reaction. In order to determine the activation energy, the rate of $\mathrm{H}_{2}$ generation was measured at different solution temperatures $\left(30-50^{\circ} \mathrm{C}\right)$.

\section{RESULTS AND DISCUSSION}

\section{Material characterization}

In our previous work [45] we have investigated the electrochemical behaviour of $\mathrm{ZnCo} / \mathrm{Ti}$ and $\mathrm{AuZn}$ $\mathrm{Co} / \mathrm{Ti}$ catalysts in $\mathrm{NaBH}_{4}$ and hydrazine $\left(\mathrm{N}_{2} \mathrm{H}_{4}\right)$ alkaline solutions and determined that both catalysts are active toward the oxidation reactions of $\mathrm{NaBH}_{4}$ and $\mathrm{N}_{2} \mathrm{H}_{4}$. However, the stability and durability of the mentioned catalysts have not been thoroughly analysed in an alkaline medium and their activity toward the hydrolysis reaction of $\mathrm{NaBH}_{4}$ remained short in detail. Therefore, following the work carried out previously, in this study we continue the investigation regarding the above-mentioned matters 
and present a more detail analysis for the BOR in an alkaline medium. Since the anodic oxidation of $\mathrm{NaBH}_{4}$ is a heterogeneous reaction, the changes in the structure and morphology of the surface of the anode material during the oxidation process is of basic importance. Therefore, it is meaningful and very reasonable to compare the physical properties of the as-prepared catalysts and those after some treatment in $\mathrm{NaBH}_{4}$ solutions. For the sake of simplicity, we briefly overview the SEM images of the as-prepared $\mathrm{ZnCo} / \mathrm{Ti}$ and $\mathrm{AuZnCo} / \mathrm{Ti}$ catalysts as was described in detail in Ref. [45] and present them in Fig. 1 under different magnifications. It was found that the $\mathrm{ZnCo}$ coating fully covers the Ti surface and produces a compact structure with a spherical cluster surface that consists of a large number of smaller nodular-shaped grains ranging from ca. 0.5 to $2.5 \mu \mathrm{m}$ in size (Fig. 1 1 a). Dipping of the as-prepared $\mathrm{ZnCo} / \mathrm{Ti}$ electrodes into the $1 \mathrm{mM} \mathrm{HAuCl}_{4}+0.1 \mathrm{M} \mathrm{HCl}$ solution for various time periods resulted in the deposition of $\mathrm{Au}$ nanoparticles that appear as bright crystallites and are homogeneously dispersed on the $\mathrm{ZnCo}$ surface (Fig. $1 \mathrm{~b}-\mathrm{d}$ ). Moreover, Au nanoparticles sized ca. 16 to $50 \mathrm{~nm}$ were deposited on the $\mathrm{ZnCo} / \mathrm{Ti}$ surface after dipping of $\mathrm{ZnCo} / \mathrm{Ti}$ electrodes into the $1 \mathrm{mM} \mathrm{HAuCl}+0.1 \mathrm{M} \mathrm{HCl}$ solution for 0.5 and $1 \mathrm{~min}$ (Fig. $1 \mathrm{~b}, \mathrm{c}$ ), whereas dipping of the $\mathrm{ZnCo} / \mathrm{Ti}$ electrode into the $1 \mathrm{mM}$ $\mathrm{HAuCl}_{4}+0.1 \mathrm{M} \mathrm{HCl}$ solution for 5 min resulted in the development of larger Au crystallites on the $\mathrm{ZnCo}$ coating surface sized in a range of ca. 50-200 nm (Fig. 1 d). Although the Au nanoparticles are hardly discernible in Fig. 1 b, c, their residence on the surface of the coating was confirmed by EDX analysis data and are summarized in Table 1. A significant amount of $\mathrm{Zn}$ and much lower amounts of $\mathrm{Au}$ and $\mathrm{Co}$ were determined on the surfaces of $\mathrm{ZnCo} / \mathrm{Ti}$ and $\mathrm{AuZnCo} / \mathrm{Ti}$ catalysts. As follows from the data in Table 1, the increase in the modification time of the $\mathrm{ZnCo}$ coating by $\mathrm{Au}$ nanoparticles leads to a higher amount of $\mathrm{Au}$ on the surface of the catalyst. The amounts of $\mathrm{Au}$ loadings on the fabricated catalysts were estimated to be 31, 63 and $306 \mu \mathrm{g} \mathrm{cm}^{-2}$ corresponding to dipping times of $0.5,1$ and $5 \mathrm{~min}$, respectively.

Table 1. Surface atomic composition of the as-prepared $\mathrm{ZnCo} / \mathrm{Ti}$ and AuZnCo/Ti catalysts determined by EDX

\begin{tabular}{c|c|c|c|c|c}
\hline \multirow{2}{*}{ Catalyst } & \multirow{2}{*}{$\begin{array}{c}\text { Au deposition } \\
\text { time, min }\end{array}$} & \multicolumn{5}{|c}{ Element, at.\% } \\
\cline { 3 - 6 } & & Au & Zn & Co & Ti \\
\hline $\mathrm{ZnCo} / \mathrm{Ti}$ & - & - & 81.32 & 18.48 & 0.22 \\
\hline $\mathrm{AuZnCo} / \mathrm{Ti}$ & 0.5 & 1.46 & 79.25 & 18.87 & 0.41 \\
\hline $\mathrm{AuZnCo} / \mathrm{Ti}$ & 1 & 3.30 & 74.81 & 21.48 & 0.41 \\
\hline $\mathrm{AuZnCo} / \mathrm{Ti}$ & 5 & 14.62 & 51.30 & 33.48 & 0.60 \\
\hline
\end{tabular}

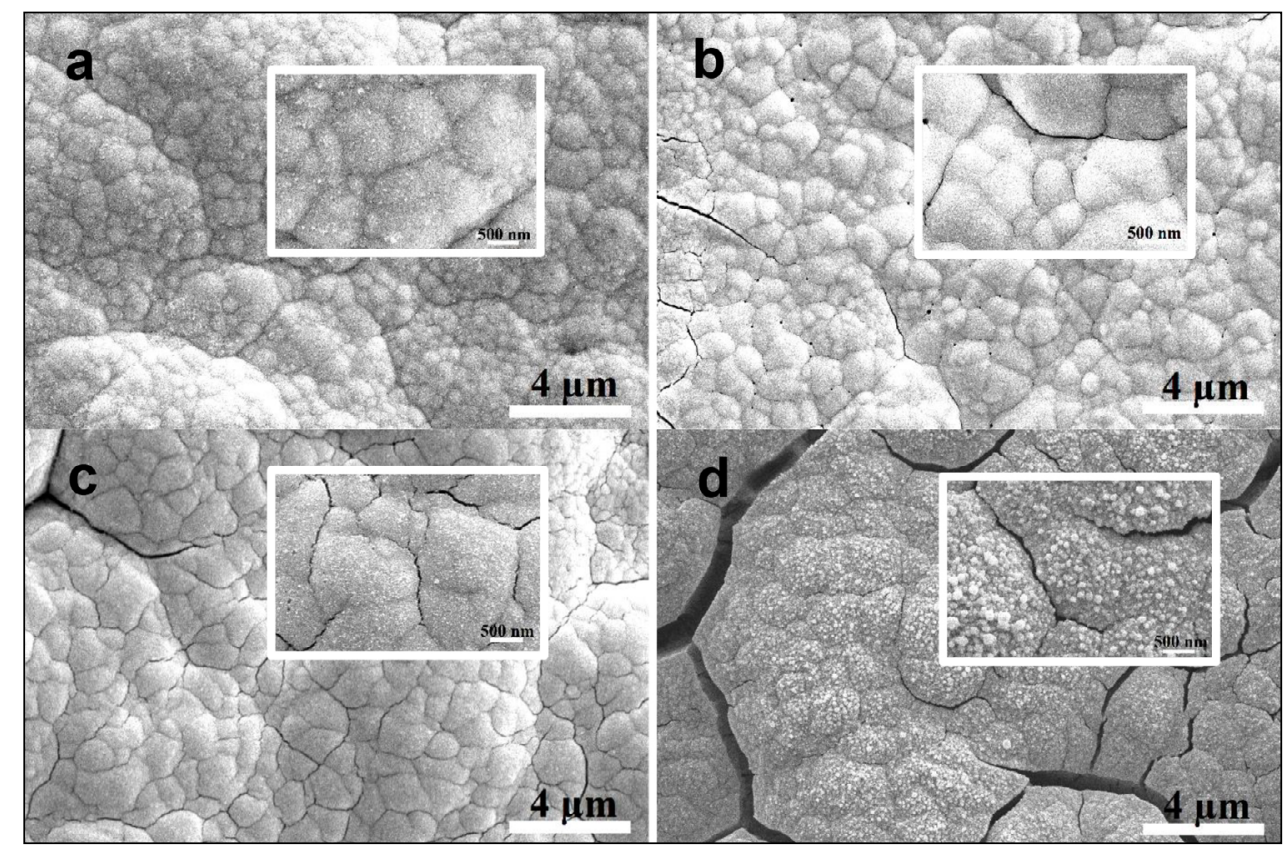

Fig. 1. FESEM images of the as-prepared $\mathrm{ZnCo} / \mathrm{Ti}$ (a) and AuZnCo/Ti catalysts (b-d). The AuZnCo/Ti catalysts were prepared by dipping of $\mathrm{ZnCo} / \mathrm{Ti}$ electrodes into a $1 \mathrm{mM} \mathrm{HAuCl}_{4}+0.1 \mathrm{M} \mathrm{HCl}$ solution at $25^{\circ} \mathrm{C}$ for 0.5 (b), 1 (c) and 5 (d) min. The insets represent the corresponding images under higher magnification 
Electrochemical activity of catalysts for the BOR In order to determine the electrochemical behaviour of the as-prepared $\mathrm{ZnCo} / \mathrm{Ti}$ and $\mathrm{AuZnCo} / \mathrm{Ti}$ catalysts for the BOR, cyclic voltammetry and chronoamperometry measurements were performed in a $\mathrm{NaBH}_{4}$ alkaline solution. The obtained results of the $\mathrm{BOR}$ on the $\mathrm{ZnCo} / \mathrm{Ti}$ and $\mathrm{AuZnCo} / \mathrm{Ti}$ catalysts were compared with each other and with those recorded on the bare Au electrode. Figure 2 presents typical $\mathrm{CV}$ results of the bare Au electrode recorded in a $0.05 \mathrm{M} \mathrm{NaBH}_{4}+1 \mathrm{M} \mathrm{NaOH}$ solution at a scan rate of $10 \mathrm{mV} \mathrm{s}^{-1}$. The bare Au electrode is characterized by the onset potential $E_{\text {onset }}$ of ca. $-0.8 \mathrm{~V}$ and by a typical current peak (denoted as A) at a potential of ca. $-0.4 \mathrm{~V}$. Anodic peak $\mathrm{A}$ is attributed to the direct and complete eight-electron oxidation of $\mathrm{BH}_{4}^{-}$ions (Eq. (1)), as discussed in Refs. [10, 46-49]:

$$
\mathrm{BH}_{4}^{-}+8 \mathrm{OH}^{-} \rightarrow \mathrm{BO}_{2}^{-}+6 \mathrm{H}_{2} \mathrm{O}+8 \mathrm{e}^{-} \text {. }
$$

The production of $\mathrm{H}_{2}$ and $\mathrm{BH}_{3} \mathrm{OH}^{-}$due to the direct heterogeneous hydrolysis presents a peak in the potential region of the first branch of the BOR wave [50, 51]. In Ref. [52] it is stated that the BOR on $\mathrm{Au}$ proceeds through the electrooxidation of $\mathrm{BH}_{3 \mathrm{ads}}$ species that originates from a partial dissociation of $\mathrm{BH}_{4}^{-}$ions, during which the self-dehydrogenation of $\mathrm{BH}_{4}^{-}$generates $\mathrm{H}_{2}$. The origin of $\mathrm{H}_{2}$ production coming essentially from the dehydrogenation of $\mathrm{BH}_{3 \mathrm{ads}}$

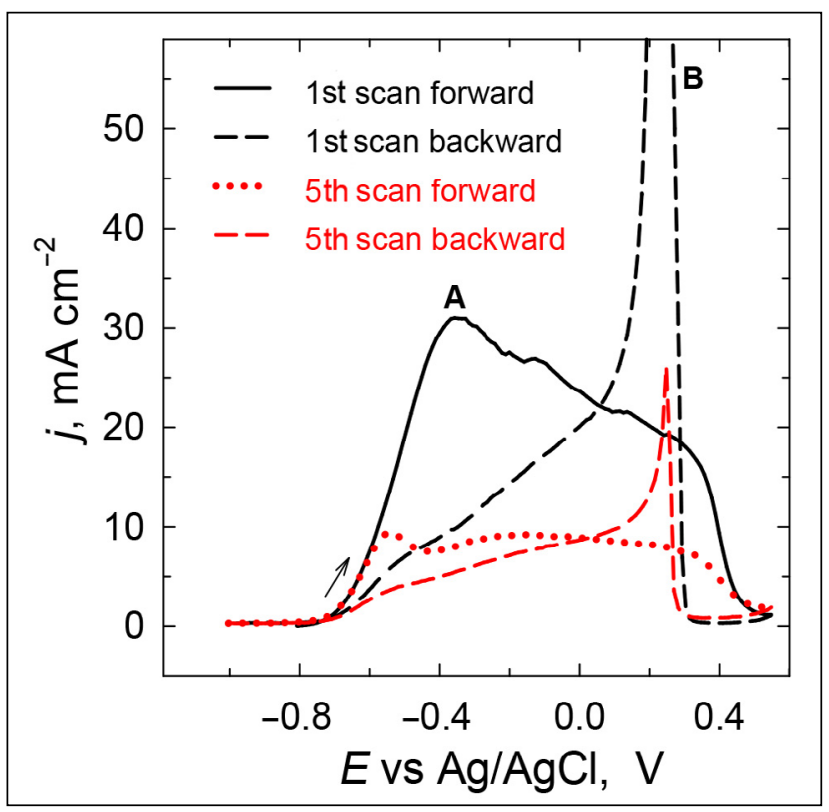

Fig. 2. CVs recorded on the bare Au catalyst in a $0.05 \mathrm{M} \mathrm{NaBH}_{4}+1 \mathrm{M}$ $\mathrm{NaOH}$ solution at a scan rate of $10 \mathrm{mV} \mathrm{s}^{-1}$, at $25^{\circ} \mathrm{C}$ (coloured online) was monitored and confirmed by differential electrochemical mass spectrometry (DEMS) [53]. Following peak $\mathbf{A}$, a wide-extended oxidation wave from ca. -0.4 up to $0.4 \mathrm{~V}$ on the bare Au catalyst appears and corresponds to the oxidation reaction of intermediates on a partially oxidized Au surface [10]. On the reverse potential scan, a sharp peak (denoted as B) is observed at ca. $0.2 \mathrm{~V}$ followed by a plateau in the potential region from 0.0 to $-0.6 \mathrm{~V}$. This peak corresponds to the oxidation of the adsorbed species such as $\mathrm{BH}_{3} \mathrm{OH}^{-}$or other borohydrides formed as intermediates during the oxidation of $\mathrm{NaBH}_{4}$ in the forward scan [10, 51]. A significant decrease in current is observed in the subsequent scan cycles in the $\mathrm{NaBH}_{4}$ solution (Fig. 2) that can be explained by the formation of intermediates that adsorb on the electrode and simultaneously poison the surface resulting in a diminished electrocatalytic activity of the bare gold electrode [10]. Figure 3 shows the electrochemical behaviour of the AuZnCo/Ti catalysts that have Au loadings of 31 (a), 63 (b) and 306 (c) $\mu \mathrm{g}_{\mathrm{Au}} \mathrm{cm}^{-2}$ in a $0.05 \mathrm{M} \mathrm{NaBH}_{4}+1 \mathrm{M} \mathrm{NaOH}$ solution at a scan rate of $10 \mathrm{mV} \mathrm{s}^{-1}$. The first potential cycles of $\mathrm{NaBH}_{4}$ oxidation onto the AuZnCo/Ti catalysts are shown in Fig. 3a-c (lines 1). The dotted lines represent the $\mathrm{CV}$ results of the above-mentioned catalysts recorded in the background solution of $1 \mathrm{M} \mathrm{NaOH}$ (Fig. 3a-c, lines 2). Consecutive anodicgoing potential scans starting from the 2 nd one for the same catalysts with the same loadings are presented in Fig. 3a'-c. The data obtained in Fig. $3 a-c$ suggest that the oxidation of $\mathrm{NaBH}_{4}$ at all the AuZn$\mathrm{Co} / \mathrm{Ti}$ catalysts that have different Au loadings starts at a significantly more negative electrode potential $E_{\text {onset }}$ of ca. $-1.2 \mathrm{~V}$ as compared to that of bare $\mathrm{Au}$ (Fig. 2). The difference in $E_{\text {onset }}$ equals to ca. $0.4 \mathrm{~V}$ and points to the presence of better fuel cells operation conditions at the AuZnCo/Ti surface. Unlike on $\mathrm{Au}$, in the CVs recorded in a $\mathrm{NaBH}_{4}$ solution on the different $\mathrm{Au}$ loading containing $\mathrm{AuZnCo} / \mathrm{Ti}$ catalysts, a set of well-expressed anodic peaks is observed (Fig. 3). A well-defined anodic peak A0 at low potential values and another broad one that collapse into a strongly resolved doublet each of them labelled as $\mathbf{A}$ and $\mathbf{A}$ ', respectively, can be observed in the CVs (Fig. $3 \mathrm{a}-\mathrm{c}$ ). The nature of anodic peak A0 recorded at AuZnCo/Ti could be ascribed to the oxidation of $\mathrm{H}_{2}$ generated by the catalytic hydrolysis of $\mathrm{NaBH}_{4}$ as well as to the oxidation of $\mathrm{NaBH}_{4}$, similarly as at the $\mathrm{ZnCo} / \mathrm{Ti}$ catalyst [44]. It 


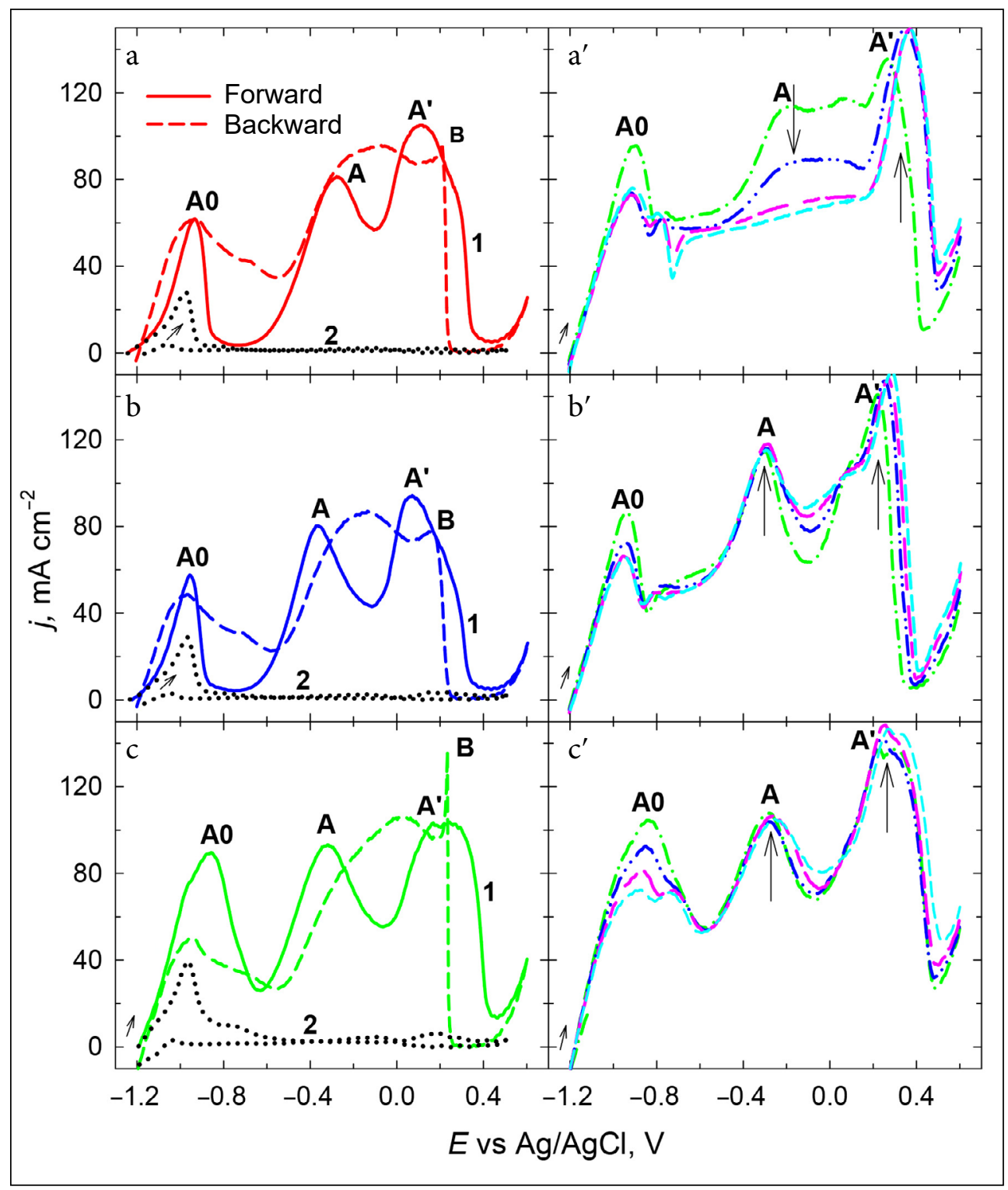

Fig. 3. The first scans of CVs recorded on the as-prepared AuZnCo/Ti catalysts with the Au loadings of 31 (a), 63 (b) and 306 (c) $\mu \mathrm{g}_{\mathrm{Au}} \mathrm{cm}^{-2}$ in $0.05 \mathrm{M} \mathrm{NaBH}_{4}+1 \mathrm{M} \mathrm{NaOH}$ (a-c, lines 1 ) and in $1 \mathrm{M} \mathrm{NaOH}$ (a-c, dotted lines 2) at a scan rate of $10 \mathrm{mV} \mathrm{s}^{-1}$, at $25^{\circ} \mathrm{C}$. ( $\left.\mathrm{a}^{\prime}-\mathrm{c}^{\prime}\right)$ Continuous positive-going potential scans starting from the second one for the same catalysts as in Fig. 3a-c (coloured online)

should be noted that anodic peak $\mathbf{A 0}$ at the $\mathrm{Zn} / \mathrm{Ti}$ catalyst occurs at ca. $-1.27 \mathrm{~V}$ and is attributed to the electrooxidation of $\mathrm{BH}_{4}^{-}$ions [54]. Meanwhile, anodic peak $\mathbf{A 0}$ for the $\mathrm{Co} / \mathrm{Ti}$ catalyst was earlier attributed only to the oxidation of $\mathrm{H}_{2}$ generated by the catalytic hydrolysis of $\mathrm{NaBH}_{4}[6,55]$. The same peak A0 for metallic Co was assigned to the direct oxidation of $\mathrm{BH}_{4}^{-}$ions [56]. Furthermore, since the oxidation of $\mathrm{NaBH}_{4}$ proceeds in a strongly alkaline solution, so anodic peak A0 may be also attributed to the formation of cobalt oxide and hydroxide according to the following reactions (Eqs. $(2,3))[57,58]$ :

$$
\begin{aligned}
& \mathrm{Co}+2 \mathrm{OH}^{-} \rightarrow \mathrm{Co}(\mathrm{OH})_{2}+2 \mathrm{e}^{-}, \\
& \mathrm{E}_{0}=-0.918 \mathrm{~V}(\mathrm{vs} \mathrm{Ag} / \mathrm{AgCl}, \mathrm{pH} 14), \\
& \mathrm{Co}+2 \mathrm{OH}^{-} \rightarrow \mathrm{CoO}+\mathrm{H}_{2} \mathrm{O}+2 \mathrm{e}^{-}, \\
& \mathrm{E}_{0}=-0.892 \mathrm{~V}(\text { vs Ag/AgCl, } \mathrm{pH} 14) .
\end{aligned}
$$

In order to better understand the low-potential processes occurring at the $\mathrm{AuZnCo} / \mathrm{Ti}$ catalyst we recorded CVs in a supporting $1 \mathrm{M} \mathrm{NaOH}$ solution and superimposed the first scans of CVs in $1 \mathrm{M} \mathrm{NaOH}$ (dotted lines 2) with the first scans in 
a $0.05 \mathrm{M} \mathrm{NaBH}_{4}+1 \mathrm{M} \mathrm{NaOH}$ solution (lines 1) in Fig. $3 \mathrm{a}-\mathrm{c}$. It is clearly seen that anodic peaks A0 recorded in an alkaline $\mathrm{NaBH}_{4}$ solution at $\mathrm{AuZnCo} /$ Ti with different Au loadings are markedly higher as compared to those recorded using the same catalyst in a $\mathrm{NaOH}$ solution. These data indicate that the major part of the charge passed in an alkaline $\mathrm{NaBH}_{4}$ solution at low potentials may be attributed to the oxidation utilization of fuel rather than the catalyst itself. At more positive potentials peak A emerges. It occurs almost in the same potential region as on the bare Au electrode [10, 46-49] and is reasonably attributed to the direct oxidation of $\mathrm{NaBH}_{4}$ at the AuZnCo/Ti catalyst. On the backward-going cathodic scan, some oxidation peaks are also observed. They could be related to the oxidation of adsorbed intermediate species that are formed during the BOR in the forward scan as well as to the reactivation of the oxidized Co and $\mathrm{Zn}$ surfaces during the previous anodic scan.

Nevertheless, the CVs recorded in a $\mathrm{NaBH}_{4}$ solution obtained at the $\mathrm{AuZnCo} / \mathrm{Ti}$ catalyst containing different $\mathrm{Au}$ loadings are similar in shape (Fig. 3a-c); however, the electrochemical behaviour of the aforementioned catalysts for the BOR during the long-term cycling (Fig. $3 a^{\prime}-c^{\prime}$ ) differs significantly. Current density values for anodic peaks $\mathbf{A 0}$ and $\mathbf{A}$ at the AuZnCo/Ti catalyst that has the Au loading of $31 \mu \mathrm{g}_{\mathrm{Au}} \mathrm{cm}^{-2}$ (Fig. 3a') appreciably increase after the first cycle applied; however, they fall down with continuous potential scans till they receive some stable state. Almost analogous behaviour of the $\mathrm{ZnCo} / \mathrm{Ti}$ catalyst towards the BOR was determined in Ref. [44], except that the decrease in current during a longterm cycling was already observed from the first scan. One reason of such a decrease in current densities can be explained by the occurrence of $\mathrm{NaBH}_{4}$ oxidation intermediate species that block the catalyst surface. On the other hand, the degradation of the catalyst should be taken into account. The observed feature points to the fact that the mentioned catalysts are not sufficiently stable and are inclined to degrade during the BOR.

A completely different tendency in current density changes under the same peaks during cycling is obtained on the catalysts that have higher Au loadings of $63 \mu \mathrm{g}_{\mathrm{Au}} \mathrm{cm}^{-2}$ (Fig. $3 \mathrm{~b}^{\prime}$ ) and $306 \mu \mathrm{g}_{\mathrm{Au}} \mathrm{cm}^{-2}$ (Fig. $3 \mathrm{c}^{\prime}$ ). The values of current densities under anodic peak $\mathbf{A}$ associated with the di- rect oxidation of $\mathrm{NaBH}_{4}$ for both catalysts increase and finally achieve almost stable ones after a few potential cycles applied, indicating a higher activity of the latter catalysts. Meanwhile, the current densities under anodic peak A0 after the second scan decrease.

To get some further information on the changes in catalyst morphology and elemental composition during the cycling in the $\mathrm{NaBH}_{4}$ solution, additional FESEM and EDX analysis was performed. Figure $4 a-d$ presents the FESEM images of the same as-prepared $\mathrm{ZnCo} / \mathrm{Ti}$ and $\mathrm{AuZnCo} / \mathrm{Ti}$ catalysts as shown in Fig. 1 $1 \mathrm{a}-\mathrm{d}$, but after 5 cycles treatment in a $0.05 \mathrm{M} \mathrm{NaBH}_{4}+1 \mathrm{M} \mathrm{NaOH}$ solution. The data in Fig. 1 a and Fig. 4a evidence that the view changes drastically after the $\mathrm{ZnCo}$ coating undergoes a treatment in a $0.05 \mathrm{M} \mathrm{NaBH}_{4}+1 \mathrm{M}$ $\mathrm{NaOH}$ solution by applying 5 cycles in the potential region from -1.2 to $+0.6 \mathrm{~V}$ at a potential scan rate of $10 \mathrm{mV} \mathrm{s}^{-1}$ at $25^{\circ} \mathrm{C}$ temperature. Continuous cycling in the $\mathrm{NaBH}_{4}$ solution results in the degradation of a compact coating and leads to the development of an uneven $\mathrm{ZnCo}$ layer with larger spaces between agglomerated granules of ca. $\sim$ several hundred $\mathrm{nm}$ in size directed both vertically and horizontally. Figure ta clearly evidences the appearance of a highly porous structure leading to significant changes in the chemical composition of the coating. The porous structure could provide the multi-channel diffusion pathways and enhance the interaction between the electrode and the electrolyte. On the other hand, although the thick volumic active layers contain numerous sites for the reaction to proceed, these sites remain insufficiently fed by a 'fresh' $\mathrm{NaBH}_{4}$ solution, since the layer feeding operates mainly only from the top of the surface [60]. However, the structure/thickness of the active layer as well as the nature and stability of the electrocatalyst is important in order to reach a high BOR efficiency.

The FESEM images of the same-prepared $\mathrm{AuZnCo} / \mathrm{Ti}$ catalysts, as shown in Fig. $1 \mathrm{~b}-\mathrm{d}$, after 5 cycles treatment in a $0.05 \mathrm{M} \mathrm{NaBH}_{4}+1 \mathrm{M}$ $\mathrm{NaOH}$ solution are shown in Fig. $4 \mathrm{~b}-\mathrm{d}$. They clearly indicate that the modification of the $\mathrm{ZnCo}$ layer by $\mathrm{Au}$ nanoparticles has a great influence on the morphology of the AuZnCo/Ti catalyst when compared to that of $\mathrm{ZnCo} / \mathrm{Ti}$ surface analogously treated in the tested solution (Fig. 4a). It results in both decrease of larger spaces between 


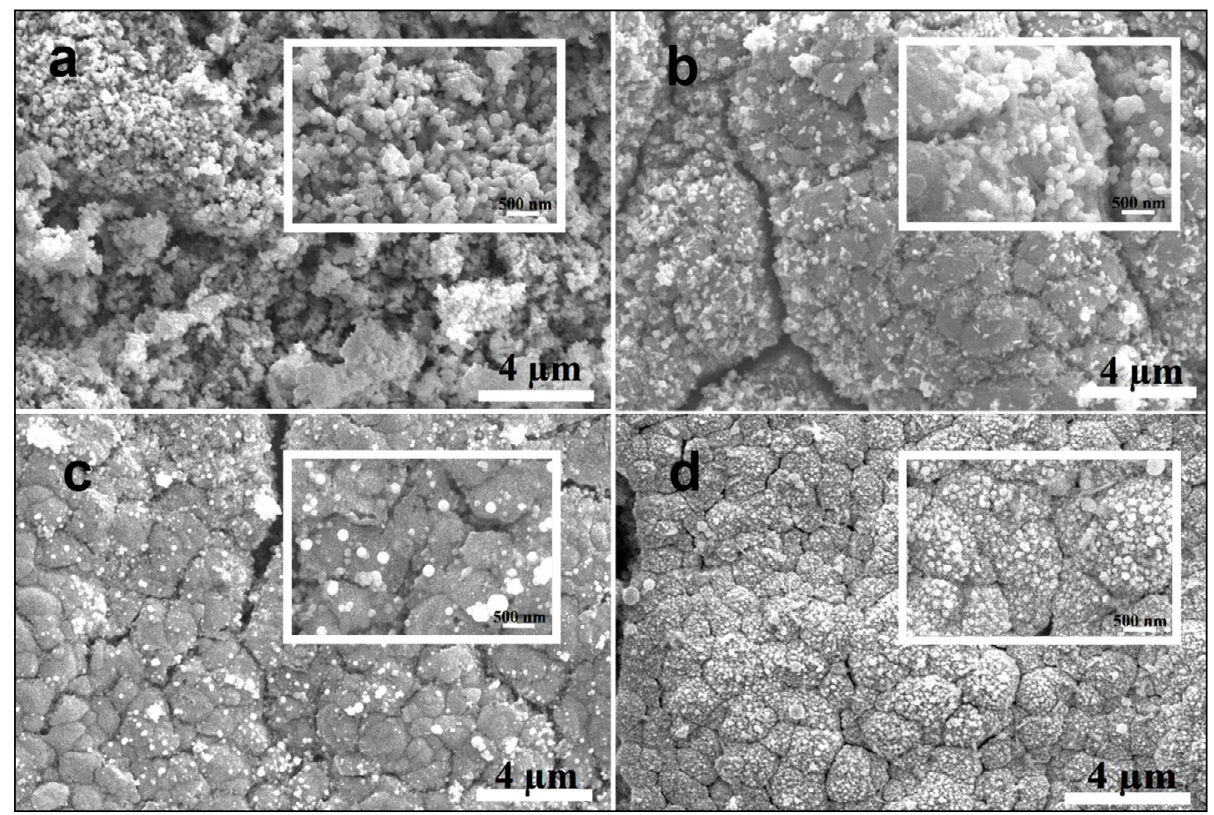

Fig. 4. FESEM images of the $\mathrm{ZnC} / \mathrm{Ti}(\mathrm{a})$ and $\mathrm{AuZnCo} / \mathrm{Ti}(\mathrm{b}-\mathrm{d})$ catalysts after 5 cycles treatment in a $0.05 \mathrm{M}$ $\mathrm{NaBH}_{4}+1 \mathrm{M} \mathrm{NaOH}$ solution by applying a potential scan rate of $10 \mathrm{mV} \mathrm{s}^{-1}$ in the potential region from -1.2 to $+0.6 \mathrm{~V}$, at $25^{\circ} \mathrm{C}$. The insets represent the corresponding images under higher magnification

agglomerated granules and the number of agglomerated ones. Increasing the modification time of the $\mathrm{ZnCo} / \mathrm{Ti}$ electrode by $\mathrm{Au}$ nanoparticles almost completely prevents the degradation of the modified catalyst during continuous cycling in a $0.05 \mathrm{M} \mathrm{NaBH}_{4}+1 \mathrm{M} \mathrm{NaOH}$ solution. Nevertheless, some separate features of porosity under the semblance of light-coloured spots are observed on the surface of the AuZnCo/Ti catalyst obtained by applying the shortest modification time periods (Fig. 4b), but they rather quickly disappear by prolonging the periods to $5 \mathrm{~min}$ (Fig. $4 \mathrm{~d}$ ). The presence of Au nanoparticles in the content of catalyst stabilizes the $\mathrm{ZnCo} / \mathrm{Ti}$ catalyst and enables one to receive almost unchanged and stable $\mathrm{AuZnCo} / \mathrm{Ti}$ catalysts, thus enhancing the utilization efficiency in order to provide considerably more stable catalytically active sites.

The data of the above FESEM images are supported by the EDX analysis and are summarized in Table 2. The presence of $\mathrm{Zn}$ and Co on the Ti surface was confirmed by energy dispersive $\mathrm{X}$-ray analysis, irrespective of whether the $\mathrm{ZnCo} / \mathrm{Ti}$ coating was exposed to cycling or not (compare Tables 1 and 2). The amount of $\mathrm{Zn}$ significally decreased from 81.32 to 14.7 at.\%, meanwhile, the content of Co and Ti increased from 18.48 to 80.40 at.\% and from 0.22 to 4.90 at.\%, respectively, if 5 cycles treatment in a $0.05 \mathrm{M} \mathrm{NaBH}_{4}+1 \mathrm{M} \mathrm{NaOH}$ solution was ap-
Table 2. Surface atomic compositions of the $\mathrm{ZnC} / \mathrm{Ti}$ and AuZnCo/ Ti catalysts after 5 cycles treatment in a $0.05 \mathrm{M} \mathrm{NaBH}_{4}+1 \mathrm{M} \mathrm{NaOH}$ solution by EDX. The ZnCo/Ti and AuZnCo/Ti catalysts are the same as in Fig. 4

\begin{tabular}{c|c|c|c|c|c}
\hline \multirow{2}{*}{ Catalyst } & \multirow{2}{*}{$\begin{array}{c}\text { Au deposition } \\
\text { time, min }\end{array}$} & \multicolumn{5}{|c}{ Element, at.\% } \\
\cline { 3 - 7 } & & $\mathbf{A u}$ & $\mathbf{Z n}$ & $\mathbf{C o}$ & $\mathbf{T i}$ \\
\hline $\mathrm{ZnCo} / \mathrm{Ti}$ & - & - & 14.70 & 80.40 & 4.90 \\
\hline $\mathrm{AuZnCo} / \mathrm{Ti}$ & 0.5 & 1.92 & 20.46 & 76.41 & 1.20 \\
\hline $\mathrm{AuZnCo} / \mathrm{Ti}$ & 1 & 3.32 & 24.56 & 70.67 & 1.45 \\
\hline $\mathrm{AuZnCo} / \mathrm{Ti}$ & 5 & 14.25 & 52.00 & 33.29 & 1.46 \\
\hline
\end{tabular}

plied. The increase in Ti content to 4.90 at.\% indicates that the dissolution of $\mathrm{Zn}$ occurs not only from the top of the $\mathrm{ZnCo}$ coating, but also from all the volume of the layer. Such a phenomenon points to the fact that $\mathrm{Zn}$ dissolves from the layer during the cycling and leads to a significant degradation of the $\mathrm{ZnCo} / \mathrm{Ti}$ coating, declaring that the $\mathrm{ZnCo}$ layer is not stable. These data are in line with our previous results [44], where current density in long-term cyclic voltammograms recorded at $\mathrm{ZnCo} / \mathrm{Ti}$ were shown finally to decrease, which indicates that the $\mathrm{ZnCo} / \mathrm{Ti}$ catalyst is not sufficiently stable during long-term cycling. Degradation of the catalyst under continuous cycling in a $0.05 \mathrm{M} \mathrm{NaBH}_{4}+1 \mathrm{M}$ $\mathrm{NaOH}$ solution at a scan rate of $10 \mathrm{mV} \mathrm{s}^{-1}$ was supposed to be related to the simultaneously occurring dissolution of $\mathrm{Zn}$ at higher potential values and 
the changes in the surface structure of cobalt after disappearing of zinc.

Comparison of the elemental content of the asprepared $\mathrm{AuZnCo} / \mathrm{Ti}$ catalysts modified at different time periods to those obtained after 5 cycles treatment in the testing solution has shown that the cycling leads to a lower amount of $\mathrm{Zn}$ dissolved from the AuZnCo/Ti catalyst when modification lasts for longer time periods. Finally, when the modification time of the catalyst in the $1 \mathrm{mM} \mathrm{HAuCl}_{4}+0.1 \mathrm{M}$ $\mathrm{HCl}$ solution was extended to $5 \mathrm{~min}$, the content of $\mathrm{Zn}$ in the $\mathrm{AuZnCo} / \mathrm{Ti}$ catalyst remained unchanged whether a cycling was applied or not. It should be also noted that the cycling does not influence the amount of $\mathrm{Au}$ in the coating.

Relaying on the aforementioned FESEM and EDX data, we can conclude that the stabilization in current density under anodic peak $\mathbf{A}$ (Fig. 3 b', c') correlates with the reciprocal relation in the changes between the amount of Au loading and the amount of $\mathrm{Zn}$ in the catalyst. The higher the loading of $\mathrm{Au}$ in the AuZnCo/Ti catalyst layer is, the greater amount of $\mathrm{Zn}$ remains in the catalyst after a continuous cycling in the $\mathrm{NaBH}_{4}$ solution. It remains practically unchanged during the cycling when the Au loading equals $306 \mu \mathrm{g}_{\mathrm{Au}} \mathrm{cm}^{-2}$. The presence of sufficient quantities of $\mathrm{Au}$ particles in the catalyst layer prevents $\mathrm{Zn}$ escape from the surface and from the changes in surface morphology (that are observed in Fig. 4a after the Zn removal) simultaneously leading to the higher stability of the $\mathrm{AuZnCo} / \mathrm{Ti}$ catalyst. It is evident that the doping of $\mathrm{ZnCo}$ layer by small amounts of more noble metal like Au determines the superior quality of the catalyst that highly depends on the amount of the Au loading used.

The comparison data of the 1 st and 5 th positive-potential going voltammograms recorded on the bare $\mathrm{Au}$ (line 1), $\mathrm{ZnCo} / \mathrm{Ti}$ (a, line 2) and AuZnCo/Ti catalysts that have different Au loadings are shown in Fig. 5. It is clearly seen that the modification of the $\mathrm{ZnCo} / \mathrm{Ti}$ catalyst with small amounts of Au nanoparticles results both in the potential shift to more negative potential values under anodic peak $\mathbf{A}$ with pronounced current peak splitting and to a significant increase in current density values under the both anodic peaks $\mathbf{A} \mathbf{0}$ and $\mathbf{A}$.

The electrochemical investigations revealed that the AuZnCo/Ti catalysts show the higher activity towards the processes occurring in the entire poten- tial region that are typically attributed to the hydrolysis reaction of $\mathrm{NaBH}_{4}$ and the oxidation of $\mathrm{NaBH}_{4}$ as compared to those at the $\mathrm{ZnCo} / \mathrm{Ti}$ catalyst and yet more on bare Au. About 1.5 and 2.6 times higher anodic current densities at the potential under peak $\mathbf{A}$ after the 1st cycle were observed at the $\mathrm{AuZnCo} / \mathrm{Ti}$ catalyst that has the Au loading of $31 \mu \mathrm{g}_{\mathrm{Au}} \mathrm{cm}^{-2}$ as compared with those at the $\mathrm{ZnCo} / \mathrm{Ti}$ and bare $\mathrm{Au}$ catalysts, respectively. The AuZnCo/Ti catalyst containing Au loadings of 63 and $306 \mu \mathrm{g}_{\mathrm{Au}} \mathrm{cm}^{-2}$ gives ca. 1.5 and 1.7 and ca. 2.6 and 3.0 times greater current densities than those at the $\mathrm{ZnCo} / \mathrm{Ti}$ and the bare $\mathrm{Au}$ electrode, respectively.

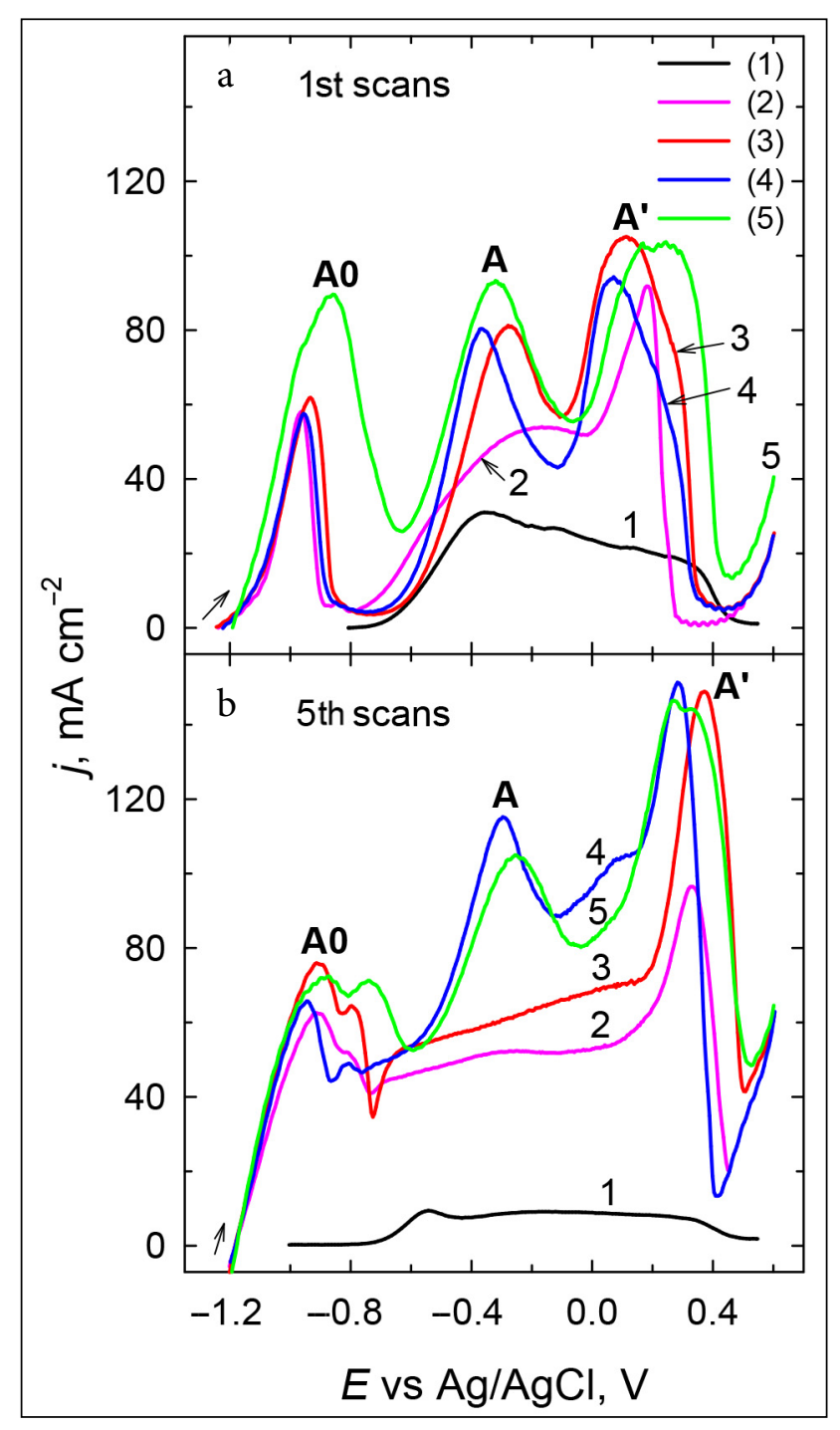

Fig. 5. (a) The first positive-going potential scans for the bare Au (line 1), ZnCo/Ti (line 2) and AuZnCo/Ti catalysts with Au loadings of 31 (line 3), 63 (line 4) and 306 (line 5) $\mu \mathrm{g}_{\mathrm{Au}} \mathrm{cm}^{-2}$ recorded in $0.05 \mathrm{M}$ $\mathrm{NaBH}_{4}+1 \mathrm{M} \mathrm{NaOH}$, at a potential scan rate of $10 \mathrm{mV} \mathrm{s}^{-1}$, at $25^{\circ} \mathrm{C}$. (b) The fifth positive-going potential scans for the same catalysts as in Fig. 5a (coloured online) 
The aforementioned increase in current under peak $\mathbf{A}$ develops yet more during the cycling since anodic current values at the $\mathrm{ZnCo} / \mathrm{Ti}$ and bare $\mathrm{Au}$ catalysts during the cycling fall down, while on the $\mathrm{AuZnCo} / \mathrm{Ti}$ catalysts that have Au loadings of 63 and $306 \mu \mathrm{g}_{\mathrm{Au}} \mathrm{cm}^{-2}$ grow up except the one with the Au loading of $31 \mu \mathrm{g}_{\mathrm{Au}} \mathrm{cm}^{-2}$. The increase in current for the aforementioned catalysts after the 5th cycle grows more than 2 times for both loadings (equals ca. 2.2 and 2.0 times higher, respectively) as compared to that of the $\mathrm{ZnCo} / \mathrm{Ti}$ catalyst, and ca. 12.19 and 11.13 times as compared to that of the bare $\mathrm{Au}$ electrode in the potential region under peak $\mathbf{A}$. Meanwhile, for the case when the Au loading was $31 \mu \mathrm{g}_{\mathrm{Au}} \mathrm{cm}^{-2}$ the increase in current as compared to that of the Au catalyst equals ca. 6.48 times, but almost no increase in current was observed as compared to that of the $\mathrm{ZnCo} / \mathrm{Ti}$ catalyst. The enhancement of the catalytic abilities of the catalyst can be attributed to the higher Au loading and to the higher number of active sites on the catalyst surface because of $\mathrm{Au}-\mathrm{ZnCo}$ interaction leading to higher activities for the BOR.

In order to compare the electrocatalytic activity of the investigated catalysts, the current density values were normalized in reference to Au loadings for each catalyst (Fig. 6). As evident, the $\mathrm{NaBH}_{4}$ oxidation current density values normalized by $\mathrm{Au}$ loadings show that the highest Au mass activity for

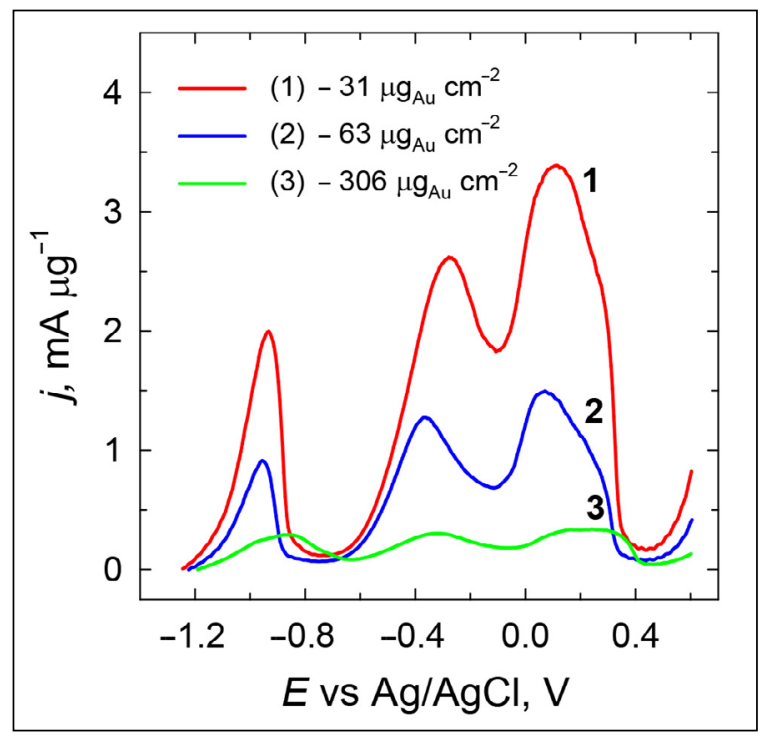

Fig. 6. Positive-potential going scans for the AuZnCo/Ti catalysts recorded in $0.05 \mathrm{M} \mathrm{NaBH}_{4}+1 \mathrm{M} \mathrm{NaOH}$ at $25^{\circ} \mathrm{C}$ at a scan rate of $10 \mathrm{mV} \mathrm{s}^{-1}$ and normalized by Au loadings for each catalyst (coloured online) the $\mathrm{BOR}$ was obtained on the $\mathrm{AuZnCo} / \mathrm{Ti}$ catalyst with the lowest Au loading of $31 \mu \mathrm{g}_{\mathrm{Au}} \mathrm{cm}^{-2}$.

To assess the catalytic characteristics of activity and stability of the AuZnCo/Ti catalysts that have different $\mathrm{Au}$ loadings chronoamperometric measurements were performed in a $\mathrm{NaBH}_{4}$ solution at a constant potential value of $-0.2 \mathrm{~V}$. The obtained data are shown in Fig. Fa. Figure $7 \mathrm{~b}$ presents the chronoamperometric curves, which were normalized by Au loadings for each catalyst. The initial current drop-off is observed, possibly due to the formation of intermediate species such as $\mathrm{BH}_{3} \mathrm{OH}^{-}$or other borohydrides [10, 46-49] during the borohydride oxidation reaction. From Fig. 7 it follows that the current density values of the investigated

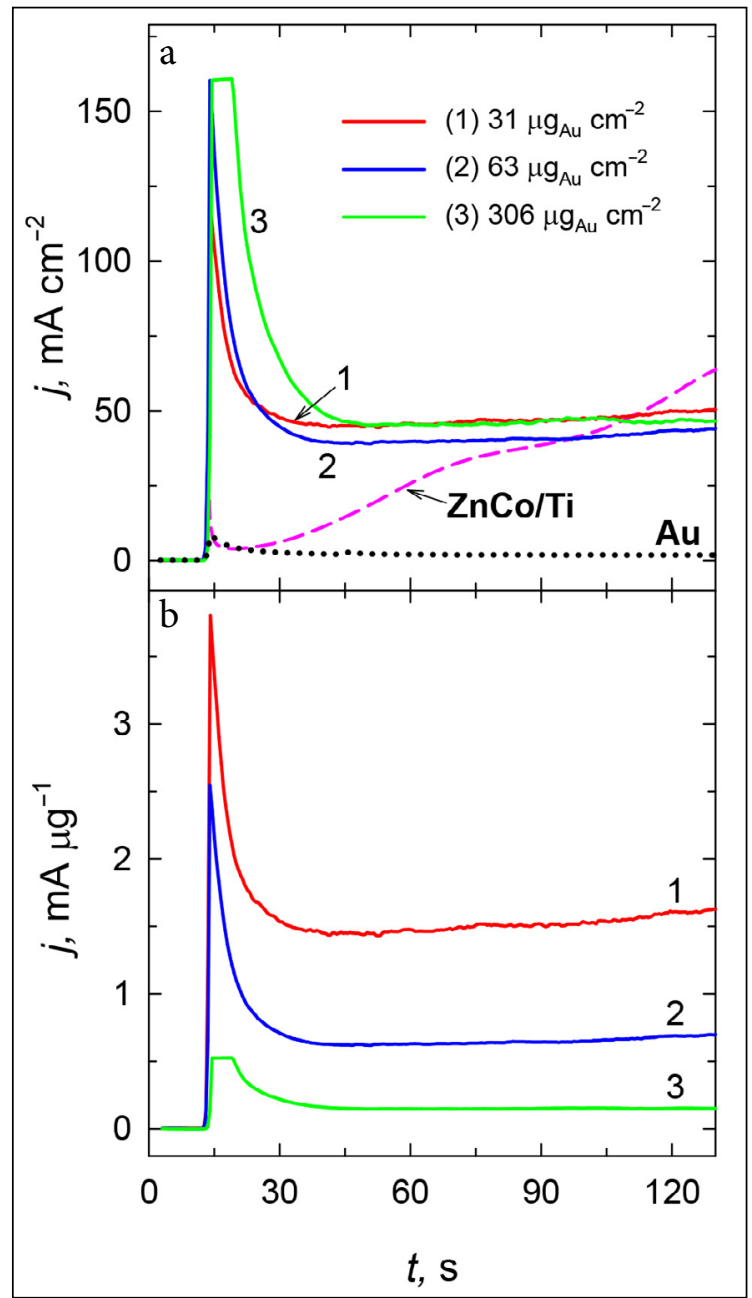

Fig. 7 (a) Chronoamperometric data for the bare Au (dotted line), ZnCo/Ti (dashed line) and AuZnCo/Ti catalysts with Au loadings of 31 (line 1), 63 (line 2) and 306 (line 3) $\mu g_{A u} \mathrm{~cm}^{-2}$ in $0.05 \mathrm{M} \mathrm{NaBH}_{4}+1 \mathrm{M} \mathrm{NaOH}$ at $-0.2 \mathrm{~V}$. The potential was initially held at an open circuit for $10 \mathrm{~s}$, then set to $-0.2 \mathrm{~V}$ for $2 \mathrm{~min}$. (b) The same data normalized by Au loadings for the AuZnCo/Ti catalysts (coloured online) 
catalysts stabilize with time and remain constant at the end period of time $(t=120 \mathrm{~s})$. The measured current densities for all the AuZnCo/Ti catalysts are higher than those for bare $\mathrm{Au}$, indicating that the former nanostructured catalysts have a higher catalytic activity for the BOR. The normalized chronoamperograms by $\mathrm{Au}$ loadings for each catalyst suggest that the catalyst with the lowest $\mathrm{Au}$ loading is the most active even though the current slightly increases at $t=45 \mathrm{~s}$ after the potential was stepped to $-0.2 \mathrm{~V}$ (Fig. $7 \mathrm{~b}$, line 1). Possibly, this is the close case as in the chronoamperogram for $\mathrm{ZnCo} / \mathrm{Ti}$ (Fig. Ba, dashed line), where two consecutive electron transfer steps for the oxidation of two oxidizable species take place [6, 7]. An enhanced electrocatalytic activity of the as-prepared $\mathrm{AuZnCo} / \mathrm{Ti}$ catalysts can be ascribed to the intrin- sic electrocatalytic activity of the Au particles deposited on the $\mathrm{ZnCo} / \mathrm{Ti}$ surface [34].

To get some information on the nature of anodic peak $\mathbf{A 0}$ and the activity of the AuZnCo/Ti catalysts in the potential domain of peak A0, the activity of the AuZnCo/Ti catalysts that have Au loadings of 63 and $306 \mu \mathrm{g}_{\mathrm{Au}} \mathrm{cm}^{-2}$ was investigated towards the hydrolysis of $\mathrm{NaBH}_{4}$. Figure 8 shows the dependence of volume of hydrogen generated during the hydrolysis reaction of the $\mathrm{NaBH}_{4}$ solution in an alkaline medium at those catalysts on the reaction temperature. The summarized data are given in Table 3. As evidenced from the data in Fig. 8, the rate of catalytic hydrolysis of $\mathrm{NaBH}_{4}$ in alkaline solutions increases exponentially with the increase of the reaction temperature, and the maximum values of 200 and $150 \mathrm{~L} \mathrm{~g}^{-1} \mathrm{~min}^{-1}$ are obtained at the aforementioned

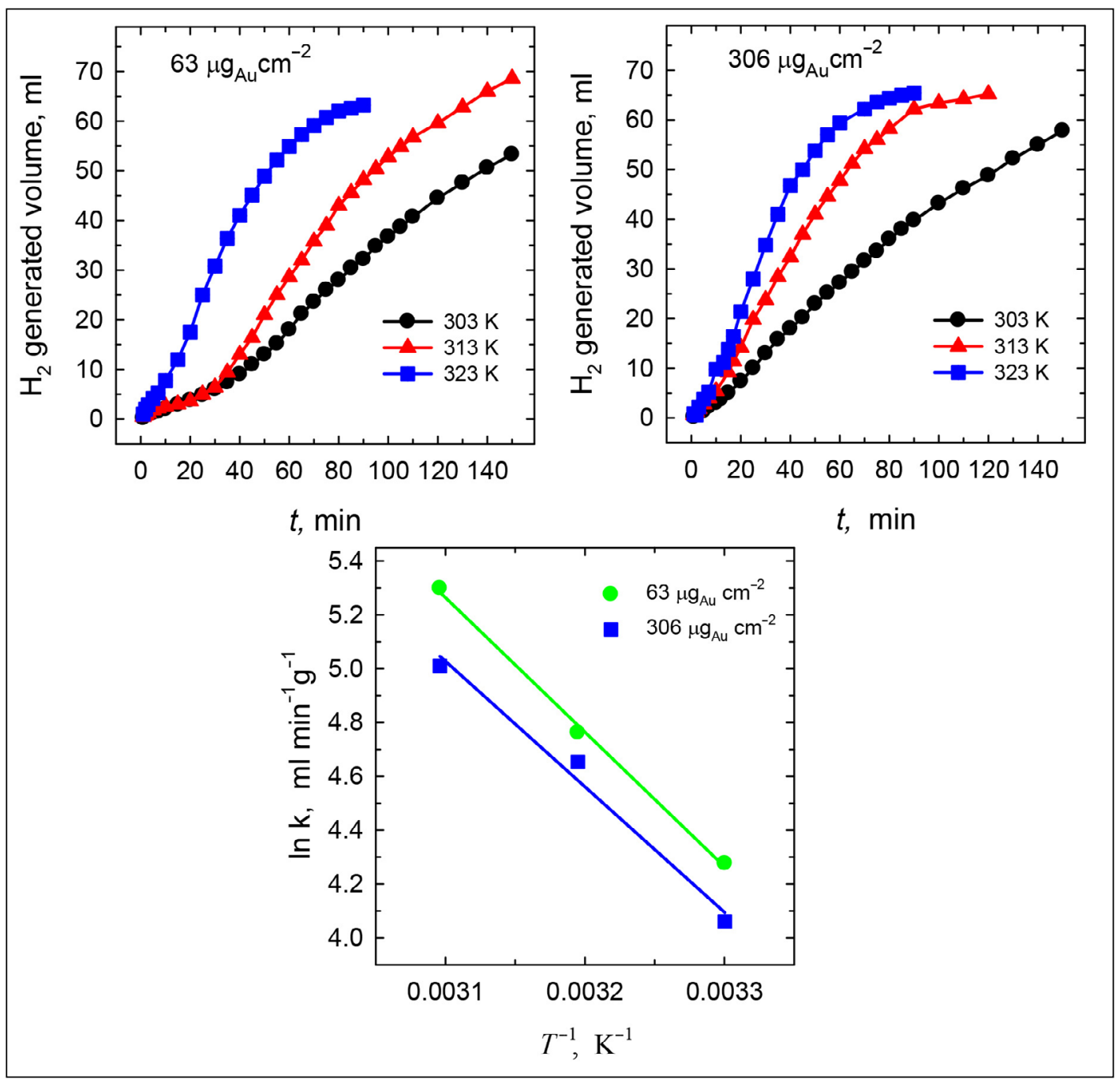

Fig. 8. $\mathrm{H}_{2}$ generation from $15 \mathrm{ml}$ of $0.05 \mathrm{M} \mathrm{NaBH}_{4}+1 \mathrm{M} \mathrm{NaOH}$ at different temperatures catalyzed by the AuZnCo/Ti catalysts that have Au loadings of 63 (a) and 306 (b) $\mu \mathrm{g}_{\mathrm{Au}} \mathrm{cm}^{-2}$. (c) The Arrhenius plots for AuZnCo/Ti calculated from the rates of $\mathrm{NaBH}_{4}$ hydrolysis in the same solution (coloured online) 
catalysts at $50^{\circ} \mathrm{C}$ temperature. The temperature dependence on the hydrogen generation rate is expressed by the Arrhenius equation

$$
\mathrm{k}=\mathrm{Ae}^{-\mathrm{Ea} / \mathrm{RT}} \text {, }
$$

where Ea is the activation energy $(\mathrm{J}), \mathrm{A}$ is the frequency factor, and $\mathrm{R}$ is the general gas constant $\left(8.314 \mathrm{~J} \mathrm{~mol}^{-1} \mathrm{~K}^{-1}\right)$. In order to find the activation energy and frequency factor, the Arrhenius plots of $\ln (\mathrm{k})$ vs $1 / \mathrm{T}$ were constructed from the data presented in Fig. 8a, b and are given in Fig. 8c.

Table 3. Dependence of the hydrogen generation rate on temperature obtained at AuZnCo/Ti in a $0.05 \mathrm{M} \mathrm{NaBH}_{4}+1 \mathrm{M} \mathrm{NaOH}$ solution

\begin{tabular}{|c|c|c|}
\hline \multirow{2}{*}{$T^{\circ}{ }^{\circ} \mathrm{C}$} & \multicolumn{2}{|c|}{$\mathrm{H}_{2}$ generation rate, $\mathrm{ml} \mathrm{g}_{\mathrm{Au}}^{-1} \mathrm{~min}^{-1}$} \\
\hline & $\begin{array}{l}\text { AuZnCo/Ti, } \\
63 \mu g_{\mathrm{Au}} \mathrm{cm}^{-2}\end{array}$ & $\begin{array}{c}\text { AuZnCo/Ti, } \\
306 \mu g_{A u} \mathrm{~cm}^{-2}\end{array}$ \\
\hline 30 & 72 & 58 \\
\hline 40 & 117 & 105 \\
\hline 50 & 200 & 150 \\
\hline
\end{tabular}

The activation energy values calculated on the basis of the Arrhenius plot on the AuZnCo/Ti catalysts that have Au loadings of 63 (a) and 306 $\mu \mathrm{g}_{\mathrm{Au}} \mathrm{cm}^{-2}(\mathrm{~b})$ are 41.5 and $44 \mathrm{~kJ} \mathrm{~mol}^{-1}$, respectively (Table 3). The comparison of the mentioned activation energies with those obtained on various catalysts reported in the literature is summarized in Table 4. It should be noted that the $\mathrm{E}_{\mathrm{a}}$ values obtained on both AuZnCo/Ti catalysts with Au load- ings of 63 and $306 \mu \mathrm{g}_{\mathrm{Au}} \mathrm{cm}^{-2}$ in a highly stabilized $0.05 \mathrm{M} \mathrm{NaBH}_{4}+1 \mathrm{M} \mathrm{NaOH}$ solution are higher than those obtained on the $\mathrm{Co}-\mathrm{B} / \mathrm{TiO}_{2}$ framework $\left(30.93 \mathrm{~kJ} \mathrm{~mol}^{-1}\right)$ [62], $\mathrm{Au}_{50} \mathrm{Ni}_{50}$ BNPs $\left(30.3 \mathrm{~kJ} \mathrm{~mol}^{-1}\right)$ [65] and $\mathrm{Au}(\mathrm{Co}) / \mathrm{Ti}\left(37.9 \mathrm{~kJ} \mathrm{~mol}^{-1}\right)$ [17] (but stability of the former catalyst was noted to be satisfactory), whereas they are almost equal to those determined on $\mathrm{ZnCo} / \mathrm{Ti}\left(40 \mathrm{~kJ} \mathrm{~mol}^{-1}\right)$,44, Co powder $\left(41.9 \mathrm{~kJ} \mathrm{~mol}^{-1}\right)$ [61] or $\mathrm{Co}-\mathrm{B} / \mathrm{Cu}$ $\left(43.3 \mathrm{~kJ} \mathrm{~mol}^{-1}\right)$ [64]. Moreover, they are lower than those on $\mathrm{Co}-\mathrm{B} / \mathrm{TiO}_{2}\left(51.6 \mathrm{~kJ} \mathrm{~mol}^{-1}\right)$ [63], Raney $\mathrm{Co}\left(53.7 \mathrm{~kJ} \mathrm{~mol}^{-1}\right)$ [61], $\mathrm{Co} / \mathrm{Ti}\left(54 \mathrm{~kJ} \mathrm{~mol}^{-1}\right)$ [44] or $\mathrm{Au}_{20} \mathrm{Ni}_{80}$ BNPs $\left(60.0 \mathrm{~kJ} \mathrm{~mol}^{-1}\right)$ [65]. The obtained data confirm that the $\mathrm{AuZnCo} / \mathrm{Ti}$ catalysts catalyze the hydrolysis reaction of $\mathrm{NaBH}_{4}$ in alkaline solutions.

\section{CONCLUSIONS}

This study is focused on the improving of the structure and operation characteristics of the costeffective $\mathrm{ZnCo} / \mathrm{Ti}$ catalyst for the oxidation of $\mathrm{NaBH}_{4}$ by modifying it with different amounts of $\mathrm{Au}$ crystallites. The activity of the prepared $\mathrm{AuZnCo} / \mathrm{Ti}$ catalysts has been also examined toward the oxidation and hydrolysis of $\mathrm{NaBH}_{4}$ in an alkaline medium. It has been determined that anodic current peaks attributed to the direct oxidation of $\mathrm{NaBH}_{4}$ are significantly higher on the AuZnCo/Ti catalysts than those on the $\mathrm{ZnCo} / \mathrm{Ti}$ catalysts and yet more on the bare Au. During the long-term cycling, the $\mathrm{AuZnCo} / \mathrm{Ti}$

Table 4. Comparison of hydrogen generation rates (HG) and activation energies $\left(E_{a}\right)$ on various catalysts

\begin{tabular}{|c|c|c|c|c|c|}
\hline Catalyst & $T,{ }^{\circ} \mathrm{C}$ & Solution & $H G, m L \min ^{-1} g^{-1}$ & $E_{a}, \mathrm{~kJ} \mathrm{~mol}^{-1}$ & Ref. \\
\hline Co-B-TiO ${ }_{2}$ framework & 30 & 1.5 wt $\% \mathrm{NaBH}_{4}+5$ wt $\% \mathrm{NaOH}$ & 1980 & 30.93 & [62] \\
\hline $\mathrm{Co}-\mathrm{B} / \mathrm{TiO}_{2}$ & 30 & 1 wt $\% \mathrm{NaBH}_{4}+3.75$ wt $\% \mathrm{NaOH}$ & 12503 & 51.6 & [63] \\
\hline Co-B/Cu sheet & 20 & 5 wt $\% \mathrm{NaBH}_{4}+1 \mathrm{wt} \% \mathrm{NaOH}$ & 7935.6 & 43.3 & [64] \\
\hline Co powder & 20 & $0.2 \mathrm{~g} \mathrm{NaBH}_{4}+10 \mathrm{wt} \% \mathrm{NaOH}$ & 126.2 & 41.9 & [61] \\
\hline Raney Co & 20 & $0.2 \mathrm{~g} \mathrm{NaBH}_{4}+10 \mathrm{wt} \% \mathrm{NaOH}$ & 267.5 & 53.7 & {$[61]$} \\
\hline $\mathrm{Co} / \mathrm{Ti}$ & 55 & $0.05 \mathrm{M} \mathrm{NaBH}_{4}+1 \mathrm{M} \mathrm{NaOH}$ & 821 & 54 & [44] \\
\hline $\mathrm{Au}(\mathrm{Co}) / \mathrm{Ti}$ & 60 & $0.05 \mathrm{M} \mathrm{NaBH}_{4}+1 \mathrm{M} \mathrm{NaOH}$ & 22600 & 37.9 & [17] \\
\hline $\mathrm{Au}_{20} \mathrm{Ni}_{80} \mathrm{BNPs}$ & 30 & $30 \mathrm{mM} \mathrm{NaBH}_{4}(\mathrm{pH} 12)$ & 2470 & 60.0 & {$[65]$} \\
\hline $\mathrm{Au}_{50} \mathrm{Ni}_{50} \mathrm{BNPs}$ & 30 & $30 \mathrm{mM} \mathrm{NaBH}_{4}(\mathrm{pH} \mathrm{12)}$ & 2597 & 30.3 & {$[65]$} \\
\hline $\mathrm{ZnCo} / \mathrm{Ti}$ & 55 & $0.05 \mathrm{M} \mathrm{NaBH}_{4}+1 \mathrm{M} \mathrm{NaOH}$ & 105 & 40.0 & [44] \\
\hline $\begin{array}{l}\text { AuZnCo/Ti, } \\
63 \mu g_{\mathrm{Au}} \mathrm{cm}^{-2}\end{array}$ & 50 & $0.05 \mathrm{M} \mathrm{NaBH}_{4}+1 \mathrm{M} \mathrm{NaOH}$ & 200 & 41.5 & This work \\
\hline $\begin{array}{c}\mathrm{AuZnCo} / \mathrm{Ti}, \\
306 \mu \mathrm{g}_{\mathrm{Au}} \mathrm{cm}^{-2}\end{array}$ & 50 & $0.05 \mathrm{M} \mathrm{NaBH}_{4}+1 \mathrm{M} \mathrm{NaOH}$ & 150 & 44.0 & This work \\
\hline
\end{tabular}


catalysts that have $\mathrm{Au}$ loadings of 63 and $306 \mu \mathrm{g}_{\mathrm{Au}} \mathrm{cm}^{-2}$ show enhanced electrocatalytic activity towards the oxidation of $\mathrm{NaBH}_{4}$ as compared to those of the $\mathrm{ZnCo} / \mathrm{Ti}$ or bare Au catalysts.

Furthermore, the modification of the $\mathrm{ZnCo} / \mathrm{Ti}$ catalyst by Au nanoparticles has a great influence on the improving morphology of the $\mathrm{AuZnCo} / \mathrm{Ti}$ catalyst, since the $\mathrm{ZnCo}$ layer supported on $\mathrm{Ti}$ is prone to degrade if it is subjected to the electrochemical treatment in the $\mathrm{NaBH}_{4}$ solution. Modification allows the AuZnCo/Ti catalyst not only to maintain a more stable coating during the continuous cycling in a $\mathrm{NaBH}_{4}$ solution as compared to the asprepared $\mathrm{ZnCo} / \mathrm{Ti}$, but also to reduce the cost of the catalyst as compared to that of bare Au.

The chronoamperometry studies also confirm the higher electrocatalytic activity of the AuZnCo/ Ti catalysts for the oxidation of $\mathrm{NaBH}_{4}$ as compared to those of the bare Au electrode.

It was shown that the AuZnCo/Ti catalysts catalyze the hydrolysis reaction of $\mathrm{NaBH}_{4}$ in alkaline solutions.

Received 5 August 2020 Accepted 31 August 2020

\section{References}

1. D. M. F. Santos, C. A. C. Sequeira, Renew. Sustain. Energy Rev., 15, 3980 (2011).

2. J.-H. Wee, J. Power Sources, 155, 329 (2006).

3. C. Ponce de Leon, F. C. Walsh, D. Pletcher, D. J. Browning, J. B. Lakeman, J. Power Sources, 155, 172 (2006).

4. J. Ma, N. A. Choudhury, Y. Sahai, Renew. Sustain. Energy Rev., 14, 183 (2010).

5. J.-H. Wee, J. Power Sources, 161, 1 (2006).

6. D. M. F. Santos, C. A. C. Sequeira, Electrochim. Acta, 55, 6775 (2010).

7. D. M. F. Santos, C. A. C. Sequeira, J. Electrochem. Soc., 157, F16 (2010).

8. F. Yang, K. Cheng, K. Ye, et al., Electrochim. Acta, 115, 311 (2014).

9. F. H. B. Lima, A. M. Pasqualeti, M. B. Molina Concha, et al., Electrochim. Acta, 84, 202 (2012).

10. E. Gyenge, Electrochim. Acta, 49, 965 (2004).

11. M. Simoes, S. Baranton, C. Coutanceau, J. Phys. Chem. C, 113, 13369 (2009).

12. L. Yi, Y. Song, X. Wang, et al., J. Power Sources, 205, 63 (2012).

13. L. Yi, Y. Song, W. Yi, et al., J. Hydrogen Energy, 36, 11512 (2011).

14. L. Yi, Y. Song, X. Liu, et al., Int. J. Hydrogen Energy, 36, 15775 (2011).
15. S. Li, L. Wang, J. Chu, H. Zhu, et al., Int. J. Hydrogen Energy, 41, 8583 (2016).

16. Z. Sukackienè, L. Tamašauskaitè-Tamašiūnaitè, A. Balčiūnaitè, et al., J. Electrochem. Soc., 162, H734 (2015).

17. L. Tamašauskaitè-Tamašiūnaitè, A. Jagminienè, A. Balčiūnaitè, et al., Int. J. Hydrogen Energy, 38, 14232 (2013).

18. L. Yi, W. Wei, C. Zhao, et al., J. Power Sources. 285 , 325 (2015).

19. D. Duan, J. Liang, H. Liu, et al., Int. J. Hydrogen Energy, 40, 488 (2015).

20. L. Tamašauskaitè-Tamašiūnaitè, A. Balčiūnaitè, D. Šimkūnaitè, A. Selskis, J. Power Sources, 202, 85 (2012).

21. L. Tamašauskaitè-Tamašiūnaitè, A. Balčiūnaitè, R. Čekavičiūtè, A. Selskis, J. Electrochem. Soc., 159, B611 (2012).

22. P. He, X. Wang, P. Fu, et al., Int. J. Hydrogen Energy, 36, 8857 (2011).

23. D. Duan, H. Liu, X. You, et al., J. Power Sources, 293, 292 (2015).

24. L. Jing, Q. Zhao, S. Chen, et al., Electrochim. Acta, 171, 96 (2015).

25. A. Balčiūnaitè, Z. Sukackienè, L. TamašauskaitèTamašiūnaité, et al., Electrochim. Acta, 225, 255 (2017).

26. L. Yi, L. Liu, X. Liu, et al., Int. J. Hydrogen Energy, 37, 12650 (2012).

27. B.Šljukić, J. Milikić, D. M. F. Santos, C. A.C. Sequeira, Electrochim. Acta, 107, 577 (2013).

28. L. Yi, W. Wei, C. Zhao, et al., Electrochim. Acta, 158, 209 (2015).

29. J. Liu, L. Yi, X. Wang, et al., Int. J. Hydrogen Energy, 40, 7301 (2015).

30. M. G. Hosseini, M. Abdolmaleki, F. Nasirpouri, Electrochim. Acta, 114, 215 (2013).

31. F. Pei, Y. Wang, X. Wang, et al., Int. J. Hydrogen Energy, 35, 8136 (2013).

32. L. Tamašauskaitè-Tamašiūnaitè, A. Balčiūnaitè, A. Zabielaite, et al., J. Electroanal. Chem., 700, 1 (2013).

33. P. He, Y. Wang, X. Wang, et al., J. Power Sources, 196, 1042 (2011).

34. P. He, X. Wang, Y. Liu, et al., Int. J. Hydrogen Energy, 37, 11984 (2012).

35. S. Papadimitriou, A. Tegou, E. Pavlidou, et al., Electrochim. Acta, 53, 6559 (2008).

36. A. Tegou, S. Papadimitriou, I. Mintsouli, et al., Catal. Today, 170, 126 (2011).

37. D. M. Yu, Y. Shen, Z. Ye, et al., Chin. Sci. Bull., 58, 2435 (2013).

38. M. G. Hosseini, M. Abdolmaleki, S. Ashrafpoor, Chin. J. Catal., 33, 1817 (2012).

39. M. Mitov, G. Hristov, E. Hristova, et al., Environ. Chem. Lett., 7, 167 (2009).

40. M. G. Hosseini, M. Abdolmaleki, Int. J. Hydrogen Energy, 38, 5449 (2012). 
41. D. Gokcen, S. E. Bae, S. R. Brankovic, J. Electrochem. Soc., 157, D582 (2010).

42. D. Gokcen, S. E. Bae, S. R. Brankovic, Electrochim. Acta, 56, 5545 (2011).

43. S. Lichušina, A. Chodosovskaja, A. Sudavičius, et al., Chemija, 19, 25 (2008).

44. L. Tamašauskaitè-Tamašiūnaitè, A. Balčiūnaitè, S. Lichušina, et al., J. Electrochem. Soc., 162, F348 (2015).

45. A. Zabielaitè, A. Balčiūnaitè, D. Šimkūnaitè, et al., Chemija, 30, 136 (2019).

46. M. V. Mirkin, A. J. Bard, Anal. Chem., 63, 532 (1991).

47. M. V. Mirkin, H. Yang, A. J. Bard, J. Electrochem. Soc., 139, 2212 (1992).

48. M. Chatenet, F. H. B. Lima, E. A. Ticianelli, J. Electrochem. Soc., 157, B697 (2010).

49. A. Igaszak, D. C. W. Kannangara, V. W. S. Lam, L. Gyenge, J. Electrochem. Soc., 160, H47 (2013).

50. P. Krishnan, T.-H. Yang, S. G. Advani, A. K. Prasad, J. Power Sources, 182, 106 (2008).

51. A. M. Pasqualeti, P.-Y. Olu, M. Chatenet, F. H. B. Lima, ACS Catal., 5, 2778 (2015).

52. P.-Y. Olu, A. Bonnefont, G. Braesch, et al., J. Power Sources, 375, 300 (2018).

53. Z. Jusys, R. J. Behm, Electrochem. Commun., 60, 9 (2015).

54. D. M. F. Santos, C. A. C. Sequeira, J. Electrochem. Soc., 157, B13 (2010).

55. D. Zhang, K. Ye, D. Cao, et al., Electrochim. Acta, 156, 102 (2015).

56. S. Amendola, P. Onnerud, M. T. Kelly, M. Binder, Talanta, 49, 267 (1999).

57. W. K. Bell, J. E. Toni, J. Electroanal. Chem., 31, 63 (1971).

58. L. D. Burke, M. E. Lyons, O. J. Murphy, J. Electroanal. Chem., 132, 247 (1982).

59. D. A. Finkelstein, R. Imbeault, S. Garbarino, et al., J. Phys. Chem. C, 120, 4717 (2016).

60. P.-Y. Olu, C. Barros, N. Job, M. Chatenet, Electrocatal., 5, 288 (2014).

61. B. H. Liu, Z. P. Li, S. Suda, J. Alloy Compd., 415, 288 (2006).

62. J. Cheng, C. Xiang, Y. Zoun, et al., Ceramics International, 41, 899 (2015).

63. Y-C. Lu, M-S. Chen, Y-W. Chen, Int. J. Hydrogen Energy, 37, 4254 (2012).

64. Y. Wang, T. Li, S. Bai, et al., Int. J. Hydrogen Energy, 41, 276 (2016).
65. X. Wang, S. Sun, Z. Huang, et al., Int. J. Hydrogen Energy, 39, 905 (2014).

Aušrinè Zabielaitė, Dijana Šimkūnaitė, Aldona Balčiūnaitė, Birutė Šimkūnaitè-Stanynienè, Irena Stalnionienè, Leonas Naruškevičius, Daina Upskuvienė, Algirdas Selskis, Loreta Tamašauskaitė-Tamašiūnaitè, Eugenijus Norkus

\section{AUKSO NANODALELĖMIS MODIFIKUOTOS CINKO-KOBALTO DANGOS STABILUMO TYRIMAS ŠARMINIAME NATRIO BOROHIDRIDO TIRPALE}

\section{Santrauka}

Darbe buvo tirtas Au nanodalelèmis modifikuotos $\mathrm{ZnCo}$ dangos, nusodintos ant titano paviršiaus ( $\mathrm{AuZnCo} / \mathrm{Ti}$ ), stabilumas šarminiame natrio borohidrido $\left(\mathrm{NaBH}_{4}\right)$ tirpale. AuZnCo/Ti katalizatoriai, turintys skirtingą Au ikrovą, buvo formuojami panaudojus elektrocheminị metalų nusodinimo ir galvaninio pakeitimo metodus. Gautų katalizatorių paviršiaus morfologija ir struktūra buvo tirta skenuojančios elektroninès mikroskopijos, rentgeno spindulių energijos dispersinès analizès ir indukciškai susietos plazmos optinès emisijos spektroskopijos metodais. Katalizatorių elektrokatalizinis aktyvumas $\mathrm{NaBH}_{4}$ oksidacijos reakcijai buvo tirtas taikant ciklinę voltamperometriją ir chromoamperometriją. $\mathrm{NaBH}_{4}$ hidrolizès reakcija šarminèje terpejje buvo tirta ant AuZnCo/Ti katalizatorių matuojant išsiskyrusio vandenilio tūrị vandens pakeitimo metodu.

Nustatyta, kad ZnCo dangos modifikavimas $\mathrm{Au}$ nanodalelèmis žymiai pagerina dangų morfologiją ir struktūrą. AuZnCo/Ti katalizatoriai, turintys nusodin-

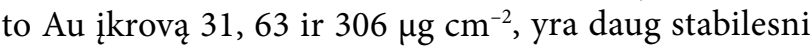
$\mathrm{NaBH}_{4}$ tirpaluose ir pasižymi didesniu elektrokataliziniu aktyvumu $\mathrm{NaBH}_{4}$ oksidacijos reakcijai, palyginti su nemodifikuotu $\mathrm{ZnCo} / \mathrm{Ti}$ katalizatoriumi, o ypač lyginant su gryno Au katalizatoriumi. Be to, kai AuZn$\mathrm{Co} / \mathrm{Ti}$ katalizatoriai, kuriuose nusodinto Au ikrova yra 63 ir $306 \mu \mathrm{g} \mathrm{cm}^{-2}$, generuoja atitinkamai apie 12 ir 11 kartų didesnes $\mathrm{NaBH}_{4}$ oksidacijos srovès tankio vertes, palyginti su vertèmis, išmatuotomis ant gryno $\mathrm{Au} \mathrm{ka-}$ talizatoriaus.

Parodyta, kad Au nanodalelèmis modifikuoti $\mathrm{ZnCo} / \mathrm{Ti}$ katalizatoriai pasižymi kataliziniu aktyvumu $\mathrm{NaBH}_{4}$ hidrolizès reakcijai šarminiuose tirpaluose. 